Article

\title{
An Effective Way to Map Land-Use Intensity with a High Spatial Resolution Based on Habitat Type and Environmental Data
}

\author{
Eliane Seraina Meier ${ }^{1, *} * \mathbb{C}$, Alexander Indermaur ${ }^{1}$, Christian Ginzler $^{2}\left(\mathbb{D}\right.$ and Achilleas Psomas ${ }^{2}$ \\ 1 Agroscope, Reckenholzstrasse 191, CH-8046 Zurich, Switzerland; alexander.indermaur@agroscope.admin.ch \\ 2 Swiss Federal Research Institute WSL, Zuercherstrasse 111, CH-8903 Birmensdorf, Switzerland; \\ christian.ginzler@wsl.ch (C.G.); achilleas.psomas@wsl.ch (A.P.) \\ * Correspondence: eliane.meier@agroscope.admin.ch; Tel.: +41-(0)58-468-74-36
}

Received: 11 February 2020; Accepted: 16 March 2020; Published: 17 March 2020

check for updates

\begin{abstract}
Mapping and monitoring agricultural land-use intensity (LUI) changes are essential for understanding their effects on biodiversity. Current land-use models provide a rather coarse spatial resolution, while in-situ measurements of LUI cover only a limited extent and are time-consuming and expensive. The purpose of this study is to evaluate the feasibility of using habitat type, topo-climatic, economic output, and remote-sensing data to map LUI at a high spatial resolution. To accomplish this, we first rated the habitat types across the agricultural landscape in terms of the amount and frequency of fertiliser input, pesticide input, ploughing, grazing, mowing, harvesting, and biomass output. We consolidated these ratings into one LUI index per habitat type that we then related to topo-climatic, economic output, and remote-sensing predictors. The results showed that the LUI index was strongly related to plant indicator values for mowing tolerance and soil nutrient content and to aerial nitrogen deposition, and thus, is an adequate index. Topo-climatic, and, to a smaller extent, economic output and remote-sensing predictors, proved suitable for mapping LUI. Large- to medium-scale patterns are explained by topo-climatic predictors, while economic output predictors explain medium-scale patterns and remote-sensing predictors explain local-scale patterns. With the fine-scale LUI map produced from this study, it is now possible to estimate within unvarying land-use classes, the effect on agrobiodiversity of an increase in LUI on fertile and accessible lands and of a decrease of LUI by the abandonment of marginal agricultural lands, and thus, provide a valuable base for understanding the effects of LUI on biodiversity. Due to the worldwide availability of remote-sensing and climate data, our methodology can be easily applied to other countries where habitat-type data are available. Given their low explanatory power, economic output variables may be omitted if not available.
\end{abstract}

Keywords: agricultural land-use intensity; agricultural input; biomass output; distribution model; habitat types

\section{Introduction}

Future growth in human population and prosperity will increase the demand for food and fuel [1]. Meeting this demand will require changes in agricultural land use [2]. Agricultural land-use change impacts biodiversity and therefore ecosystem services [3-5]. Biodiversity loss from agricultural land-use change occurs due to changes in landscape composition (i.e., proportion of cultivated land), landscape configuration (i.e., spatial arrangement of landscape elements), and land-use intensity (LUI) (i.e., number of inputs and outputs) [5-8]. In western Europe, land resources that are suitable for agricultural cultivation are becoming scarce, and thus, there are limited opportunities for increasing the proportion of cultivated land without very high costs, which are economically not profitable [9]. Therefore, changes in LUI are most important [8]. 
Land-use intensification involves the introduction of high-input arable systems on fertile and accessible lands, along with the abandonment of marginal agricultural lands [10,11]. This leads to the loss of semi-natural areas [12], to an increase in habitat fragmentation [8], to an alteration of habitat types [13], and to natural succession on marginal land [14,15]. Yet, land-use science has mainly focused on broad land-cover conversions, while spatial patterns in LUI within cropland, grazing, and mowing systems remain highly unclear [16-18]. Furthermore, studies that assess the effect of LUI on biodiversity assume that intensively used agricultural land, which surrounds semi-natural habitats, is entirely unsuitable for most species, based on the island biogeography theory. These studies measure LUI as the area of, or distance to, semi-natural habitats such as woody elements [19-22]; the percentage of permanent grassland [23]; the percentage of arable fields [24]; or broad habitat classes [25]. However, it is now acknowledged that intensively used agricultural land may not always be entirely unsuitable [26-28]. Some agricultural resources have positive consequences for species' persistence, dispersal, and colonisation [29-31]. The failure to address LUI more precisely has limited scientists' ability to make credible evaluations of the impacts of changes in land use and land cover on biodiversity in a changing climate [17,32]. A finely graduated index with a high spatial resolution may provide vital information on the effects of LUI on biodiversity.

To map LUI with a high spatial resolution, LUI has to be first parametrised and then spatialised. LUI can be parametrised by defining it as the combined effect of agricultural inputs (e.g., fertiliser, pesticide, ploughing) and biomass outputs (e.g., grazing, mowing, harvest) [33,34]. These components of LUI are currently spatialised by remote-sensing approaches, land-use models, and farmer interviews. Remote-sensing approaches primarily map LUI components by analysing temporal profiles of vegetation indices $[35,36]$. Before the launch of Sentinel satellites, remote-sensing approaches were mainly based on moderate resolution imaging spectroradiometer (MODIS; [35,37]), and thus had a rather low spatial resolution. In recent years, several studies have been developed that either use Sentinel-2 [38,39], or Sentinel-1 and Sentinel-2 combined [40,41]. Overall, remote-sensing approaches mostly focus on individual agricultural land-use classes (e.g., field crops [40], grassland [36]), or a few LUI components (e.g., biomass removal [42] or grassland mowing frequency [39]), without including ancillary predictors such as climate or topography, despite the fact that patterns on regional and global scales may strongly be topo-climatically determined. Current land-use models provide a detailed picture of the dynamics of land use [43], but the maps' spatial resolution is too low for biodiversity analyses. Spatially explicit information for individual pieces of land from elaborate, detailed interviews with farmers [44,45] are very costly to compile and can be unreliable. Because land-use activities take place in production systems that are defined by their biophysical and economic properties [16], a new approach based on spatially explicit habitat-type data, topo-climatic data, economic output data, and remote-sensing data may help map LUI at a higher spatial resolution.

In the new approach, LUI parameters are derived from habitat types, i.e., areas with particular environmental conditions and management regimes that are sufficiently uniform to support a characteristic assemblage of organisms. Habitat type-specific ratings of agricultural inputs and biomass outputs are then assembled into an LUI index that can be spatialised. This spatialization is done by topo-climatic data that characterise the biophysical properties, economic output data that describe the economic properties, and remote-sensing data that address the actual local agricultural management, i.e., agricultural input and biomass output, which are constrained by the biophysical and economic properties.

In this paper, we (1) evaluate the feasibility of creating an LUI index by rating the agricultural inputs and biomass outputs per habitat type, (2) evaluate the feasibility of mapping this LUI index at a high spatial resolution by using topo-climatic data, economic output data, and remote-sensing data, and (3) evaluate the relative importance of the three predictor sets for determining LUI. 


\section{Materials and Methods}

\subsection{Framework}

We selected the agricultural area of Switzerland as the study area. First, we created an expert-based LUI index for all 96 habitat types that typically occur in the agricultural landscape of Switzerland, as shown in Figure 1. We used a combined index of input and output, since these two dimensions of the LUI are not independent of each other. For example, fertiliser applications are often required to allow for higher mowing frequencies [46]. We evaluated the LUI index by correlating it to plant indicator values for mowing tolerance and soil nutrient content based on the plant communities from Switzerland's farmland species and habitat monitoring program (ALL-EMA). Additionally, we compared the LUI index of these plots to the aerial nitrogen deposition map, which indicates different aspects of livestock breeding (housing, storage, and application of manure, grazing) and plant production (mineral fertilisers on cropland, grassland, and alpine pastures). To create the LUI maps, we spatially predicted the LUI index assigned to each ALL-EMA plot with the help of topo-climatic predictors (i.e., climate, topography, and soil), economic output predictors (i.e., agricultural standard outputs) and remote-sensing predictors (i.e., Normalised Difference Vegetation Index) based on data from Sentinel-2 sensors. Further, we estimated the relative importance of the three predictor sets for determining LUI using a variation partitioning analysis.

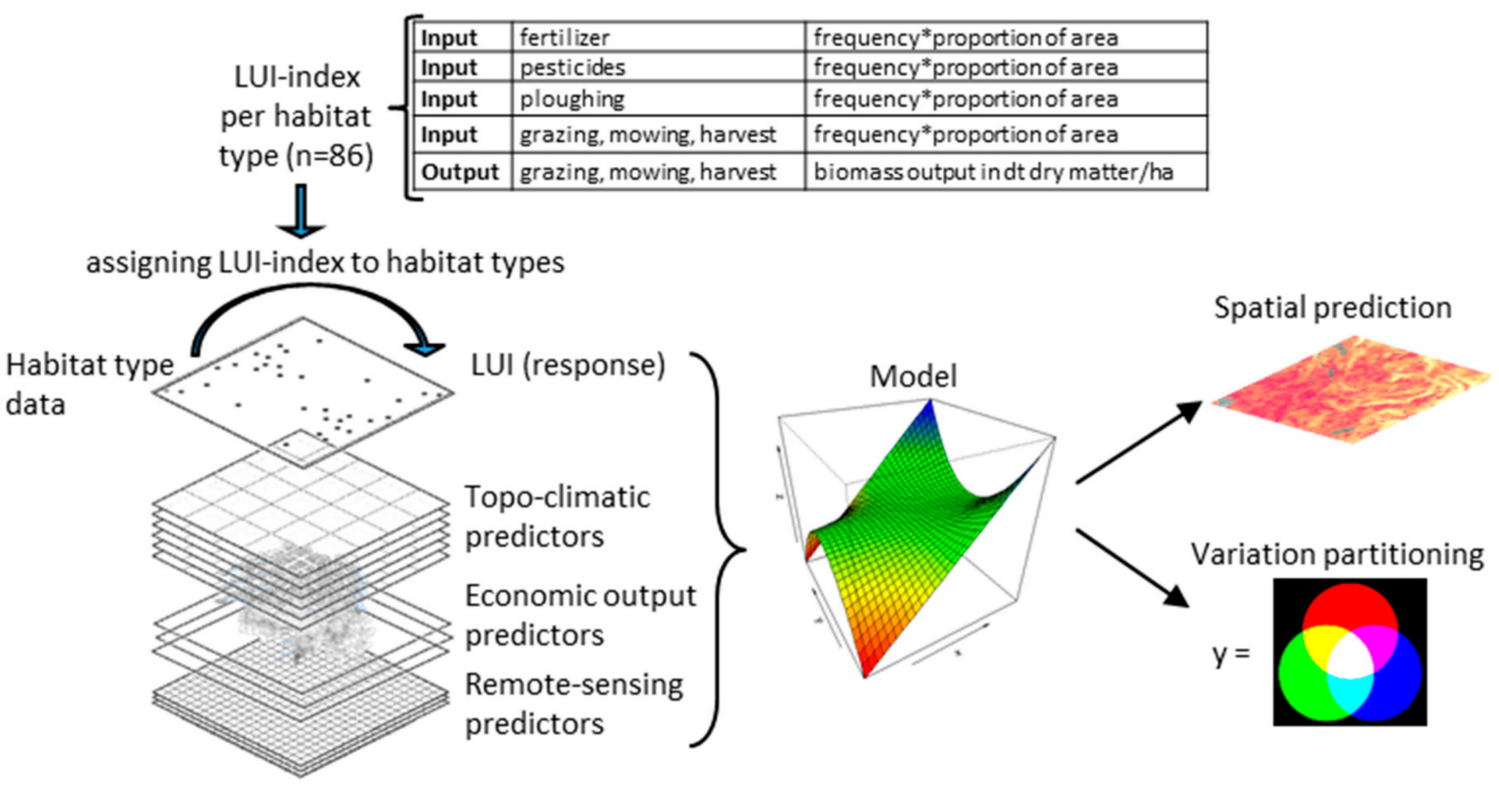

Figure 1. Framework for creating, predicting, and evaluating a land-use intensity (LUI) index.

\subsection{Study Area}

The study area was located in and along the central Alps in Switzerland $\left(45^{\circ} 49^{\prime} \mathrm{N}-47^{\circ} 48^{\prime} \mathrm{N}\right.$, $5^{\circ} 57^{\prime} \mathrm{E}-10^{\circ} 29^{\prime} \mathrm{E} ; \sim 41,000 \mathrm{~km}^{2}$ ). North of the Alps, the climate is moist and maritime. The climate is drier and more continental in the interior Alpine valleys, and the southern climate is mild and humid. The Alps act as a barrier that separates the climates of the Mediterranean and central Europe. The study area is the agricultural landscape and encompasses approximately $15,000 \mathrm{~km}^{2}$ (Figure 2). 


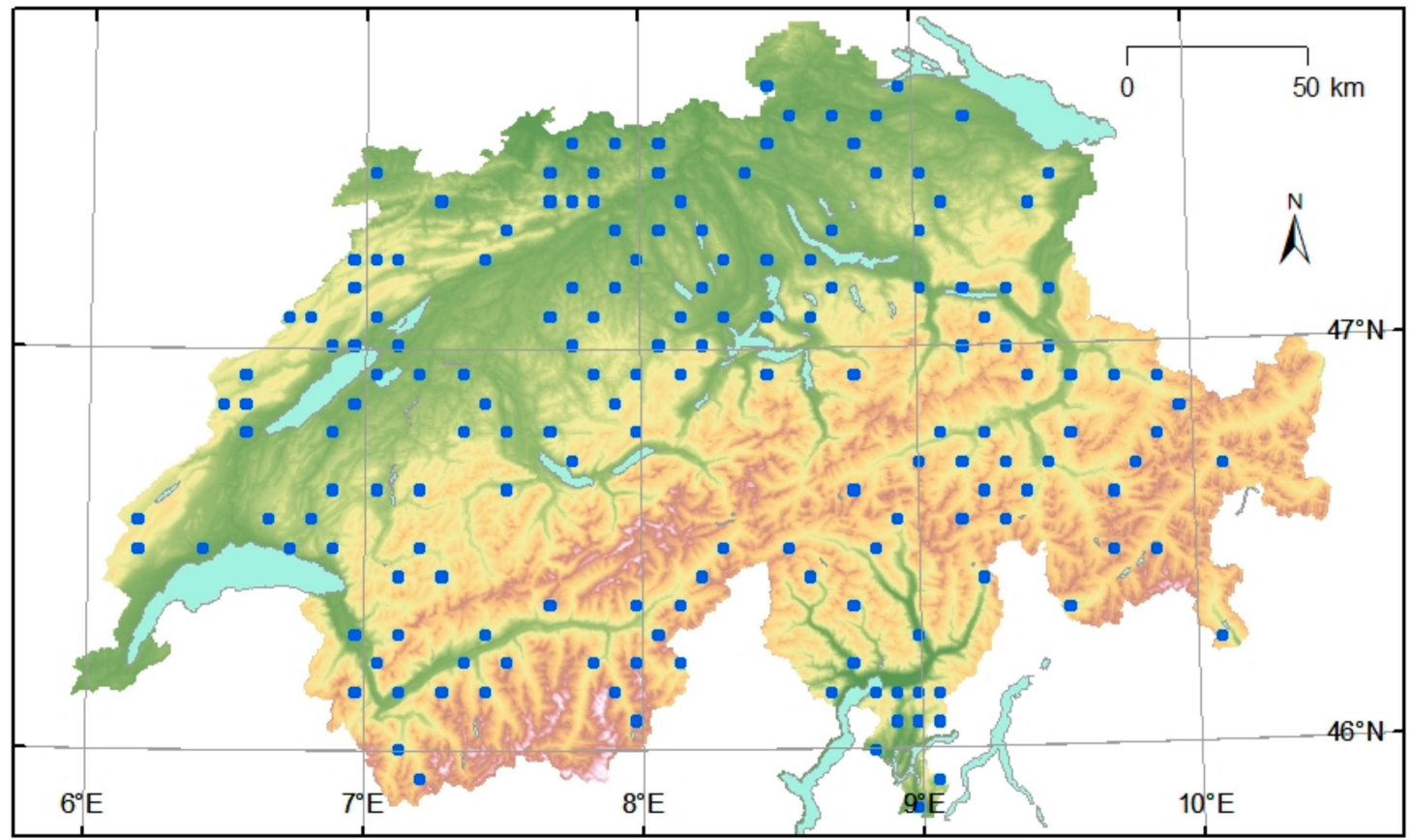

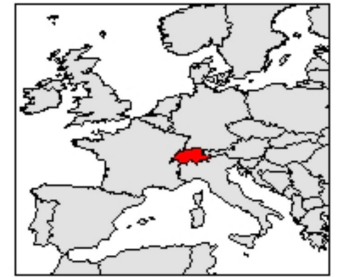

Position of Switzerland (red) in Europe

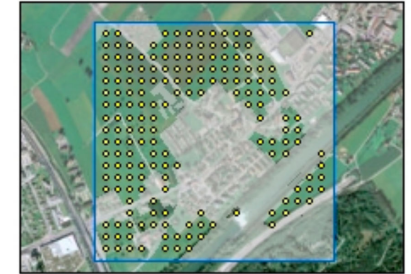

ALL-EMA $1 \mathrm{~km}^{2}$ square with sampling plots (built-up areas, roads and forests in grey are excluded)

Figure 2. Location of study area showing the 170 landscape squares of Switzerland's farmland species and habitat monitoring program ALL-EMA (blue squares) and the farmland species and habitat monitoring plots within the agricultural landscape on a $50 \mathrm{~m}$ mesh (yellow dots).

\subsection{Data}

\subsubsection{Habitat Types, Plant Species, and Plant Indicator Values}

Data on habitat types and vascular plant species originated from Switzerland's farmland species and habitat monitoring program (ALL-EMA; www.allema.ch). ALL-EMA performs surveys every five years on a given plot; the first five-year cycle started in 2015. Data are collected within the open agrarian landscape in $1701 \mathrm{~km}^{2}$ landscape squares distributed across Switzerland (Figure 2). Habitat-type data were collected from circular plots with a size of $10 \mathrm{~m}^{2}$ located on a regular grid of $50 \mathrm{~m}$. Forest, settlement, water bodies, glaciers, and rocks within the squares were not sampled. Data on vascular plants were obtained from a subsample of 19 plots. For the years 2015-2019, habitat-type information was available for 30,560 plots, and 3050 plots had a complete survey of vascular plants.

Plant indicator values for mowing tolerance and soil nutrient content are derived from Landolt et al. [47]. Mowing tolerance indicates the tolerance to a certain frequency of mowing or grazing. Soil nutrient content indicates the amount of available nitrogen and phosphorous in the soil. Indicator values range from 1 to 5 . Low values indicate low mowing tolerance or low soil nutrient content, and high values indicate high mowing tolerance or high soil nutrient content. For each of the 3050 plots where we had a complete survey of vascular plants, mean indicator values were derived by calculating a plant cover [48] weighted mean of the indicator values. 


\subsubsection{Topo-Climatic, Economic, and Remote-Sensing Data}

Topo-climatic, economic, and remote-sensing variables were selected based on their relevance to agricultural land use, plant physiology, and explaining spatial patterns. In total, 14 variables were selected (Table 1), which had a $\left|r_{s}\right|<0.7$ [49] and a Variance Inflation Factor $<5$ [50,51] to reduce multicollinearity problems. All variables were generated with R [52] and ArcGIS 10.3 [53] and resampled to a $10 \mathrm{~m}$ spatial resolution.

In terms of topo-climatic variables, we selected topographic, climatic, and edaphic variables. The topographic variables used are slope $\left(^{\circ}\right)$, potential yearly global radiation $\left(\mathrm{kJ} \mathrm{m}^{-2} \mathrm{~d}^{-1}\right)$, and topographical position index $(\mathrm{m})$, which were all computed from a $25 \times 25 \mathrm{~m}$ digital elevation model [54]. For climatic variables, we selected annual degree-days using a $0{ }^{\circ} \mathrm{C}$ threshold $\left({ }^{\circ} \mathrm{C} \mathrm{d}\right)$, summer frost days (d), and yearly precipitation days (d), which were all calculated from downscaled monthly temperature and precipitation maps (reference period 1950-2000) [55-57]. We selected soil suitability for agricultural land-use as an edaphic variable (soil suitability map of Switzerland [58]).

Standard output coefficients for Swiss agriculture describe the average monetary value of agricultural production at producer prices. We used average standard output coefficients for animal and crop production for 2005-2009 from the AGIS database [59]: cattle, sheep, and goats (AGIS-codes 1110-1586 and 1882); pigs and poultry (AGIS-codes 1611-1881); crop area (AGIS-codes 501-598); permanent crops (AGIS-codes 701-798); and protected crops (AGIS-codes 801-898). We omitted coefficients for meadows and pastures (AGIS-codes 601-698) because they were highly correlated with the coefficients for cattle, sheep, and goats, as pasture is their main forage. To approximate average standard output coefficients per pixel, we divided the summed average standard output coefficients per community by the community size.

For remote-sensing data, we used the Normalised Difference Vegetation Index (NDVI), which is strongly correlated with aboveground net primary productivity. We selected the mean and standard deviation for the growing seasons (March-October) [60,61] of 2016-2019 from Sentinel-2. The mean is a linear estimator of annual primary production, which is one of the most integrative descriptors of ecosystem functioning [62], while the standard deviation is a descriptor of the differences in carbon gains between seasons $[60,61]$. The Sentinel-2 sensor has a spatial resolution of $10 \mathrm{~m}$, a maximal revisiting time of 3-5 days, and has been available as of July 2015.

To evaluate the LUI index, we used, amongst others, the aerial nitrogen deposition ( $\mathrm{kg} \mathrm{N} / \mathrm{ha}{ }^{*}$ year) map from 2010 with a $200 \mathrm{~m}$ resolution [63]. The nitrogen deposition of the year 2010 amounts to $16.3 \mathrm{~kg} \mathrm{ha}^{-1} \mathrm{a}^{-1}$, to which gaseous $\mathrm{NH}_{3}$ contributes the largest share. The atmospheric deposition of gaseous $\mathrm{NH}_{3}$ is strongly correlated with the spatial distribution of $\mathrm{NH}_{3}$ emissions. The main source of the Swiss $\mathrm{NH}_{3}$ emissions is Swiss agriculture, especially the livestock, which accounts for about $92 \%$ of total ammonia emissions. 
Table 1. Overview of the topo-climatic, economic, and remote-sensing variables and the nitrogen deposition data.

\begin{tabular}{|c|c|c|c|c|}
\hline Predictor Set & Variable Name/Description & Range (min, max) & Unit & Source \\
\hline Topo-climatic & Degree-days with a $0{ }^{\circ} \mathrm{C}$ threshold & $0-45,832$ & ${ }^{\circ} \mathrm{Cd}$ & $\begin{array}{l}\text { Wordclim data of 1950-2000 [55] downscaled with } \\
\text { Daymet following Thornton et al. [64] according to } \\
\text { Zimmermann and Kienast [56]. }\end{array}$ \\
\hline Topo-climatic & Yearly precipitation days & $20-59$ & d & $\begin{array}{l}\text { Wordclim data of 1950-2000 [55] downscaled with } \\
\text { Daymet following Thornton et al. [64] according to } \\
\text { Zimmermann and Kienast [56]. }\end{array}$ \\
\hline Topo-climatic & Slope & $0-88$ & $\circ$ & Calculated with ArcGIS from DHM25 [54]. \\
\hline Topo-climatic & Potential yearly global radiation & $2,180-23,443$ & $\mathrm{~kJ} \mathrm{~m}^{-2} \mathrm{~d}^{-1}$ & $\begin{array}{l}\text { Calculated according to Zimmermann and Kienast } \\
\text { [56] from DHM25 [54]. }\end{array}$ \\
\hline Topo-climatic & Topographic position index & $616-1589$ & $\mathrm{~m}$ & $\begin{array}{l}\text { Calculated according to Zimmermann and Kienast } \\
\text { [56] from DHM25 [54]. }\end{array}$ \\
\hline Topo-climatic & Summer frost days & $0-8,8154$ & d & $\begin{array}{l}\text { Wordclim data of 1950-2000 [55] downscaled with } \\
\text { Daymet following Thornton et al. [64] according to } \\
\text { Zimmermann and Kienast [56]. }\end{array}$ \\
\hline Topo-climatic & Soil suitability for agricultural land-use & $1-18$ & - & Soil suitability map of Switzerland [58]. \\
\hline Remote sensing & Mean NDVI & $-1-1$ & - & Sentinel-2 (ESA) \\
\hline Remote sensing & SD NDVI & $0-0.3$ & - & Sentinel-2 (ESA) \\
\hline Economic output & $\begin{array}{c}\text { Agricultural standard output coefficient of } \\
\text { cattle, sheep, and goats (AGIS-codes } \\
1110-1586 \text { and 1882) }\end{array}$ & $0-79,603$ & CHF km $\mathrm{km}^{-2}$ & AGIS database for the years 2005-2009 [59]. \\
\hline Economic output & $\begin{array}{l}\text { Agricultural standard output coefficient of } \\
\text { pigs and poultry (AGIS-codes 1611-1881) }\end{array}$ & $0-38,202$ & CHF km $\mathrm{km}^{-2}$ & AGIS database for the years 2005-2009 [59]. \\
\hline Economic output & $\begin{array}{l}\text { Agricultural standard output coefficient } \\
\text { crop area (AGIS-codes 501-598) }\end{array}$ & $0-114,802$ & CHF km ${ }^{-2}$ & AGIS database for the years 2005-2009 [59]. \\
\hline Economic output & $\begin{array}{l}\text { Agricultural standard output coefficient of } \\
\text { permanent crops (AGIS-codes 701-798) }\end{array}$ & $0-184,619$ & CHF km ${ }^{-2}$ & AGIS database for the years 2005-2009 [59]. \\
\hline Economic output & $\begin{array}{l}\text { Agricultural standard output coefficient of } \\
\text { protected crops (AGIS-codes 801-898) }\end{array}$ & $0-178,432$ & CHF km ${ }^{-2}$ & AGIS database for the years 2005-2009 [59]. \\
\hline Aerial nitrogen deposition & Aerial nitrogen deposition (critical loads) & $2-50$ & $\mathrm{~kg} \mathrm{ha}^{-1} \mathrm{y}^{-1}$ & Rihm and Achermann [63]. \\
\hline
\end{tabular}




\subsection{LUI Index per Habitat Type}

\subsubsection{Parametrisation}

For the parametrisation of the index, we rated the LUI of each habitat type (classified according to Delarze and Gonseth [65]) associated with the agricultural landscape (see Appendix A). Each habitat type was rated separately in terms of fertiliser and pesticide input (frequency and proportion of area); ploughing (frequency and proportion of fallow area); grazing, mowing, harvesting (frequency and proportion of area); and biomass output (dt dry matter/ha/y) (Table 2). In order to derive only a single LUI index per habitat type [33], we first summed all input ratings, as they are all ratings of the frequency of treatments and the proportion of area where the treatments were applied. To enable a combined index of input and output ratings, which have different quantities, we standardised the summed input ratings and the output ratings between 0 and 0.5 , and then summed the standardised input and output ratings. The resulting LUI index ranges from 0 (i.e., no land use) to 1 (maximum LUI). The ratings for all habitat types before summing and standardising are given in Appendix A.

Table 2. Rating scheme of habitat types.

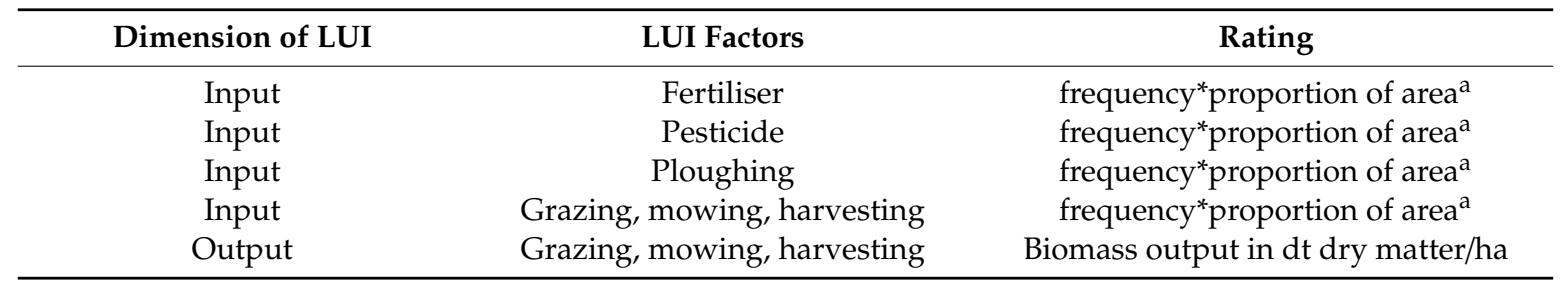

a the "frequency*proportion of area" considers the amount of area which is treated per year. For example, if only half of the area is treated once per year, then the rating is 0.5 , and if the treatment is applied to the entire area three times per year, then the rating is 3 .

\subsubsection{Evaluation}

We evaluated the LUI index by correlating (i.e., Pearson correlation) the assigned LUI index of the habitat types from ALL-EMA with plant indicator values for mowing tolerance and soil nutrient content [66] of the vegetation samples from ALL-EMA. Additionally, we correlated the LUI index of these plots to the aerial nitrogen deposition map.

\subsection{LUI Map and Variation Partitioning}

We built generalised linear models (GLMs) with logit links, assuming a binomial distribution of LUI and its components. The predictor variables (topo-climatic, economic output, and remote-sensing variables) were entered as linear and quadratic terms to allow for non-linear responses. Backward and forward stepwise variable selection was based on the Bayesian information criterion (BIC). Model fit was evaluated by the adjusted $D^{2}$ to calculate the amount of deviance accounted for by a GLM, thus allowing direct comparison amongst different models $[67,68]$. We validated model accuracy by estimating the coefficient of determination, $\mathrm{R}^{2}$ [69], the mean absolute error (MAE) [70], and the root mean square error (RMSE) [70] using a 10-fold cross-validation [71].

We evaluated the contribution of the three predictor variable sets (i.e., topo-climatic, economic output, and remote-sensing variables) to explain patterns of LUI using a variation partitioning analysis [72,73]. The contribution of each predictor set was estimated by subtracting the model fit of the model that includes the other two predictor sets from the model fit of the model that includes all three predictor sets. The joint contribution of each predictor set was estimated by subtracting the individual contribution from the model fit of the model that includes only the predictor set of interest.

In order to visualise the spatial scale on which the three predictor sets affect the spatial pattern of LUI, we spatially predicted LUI based on all three predictor sets, only on climate, topography, and soil predictors, only on economic predictors, and only on remote-sensing predictors. 


\section{Results}

\subsection{LUI Index Evaluation}

The LUI index of the ALL-EMA plots was strongly positively correlated with aerial nitrogen deposition $\left(r_{p}=0.67, P<0.0001\right)$. In addition, on the subset of plots with a full vegetation survey, the LUI index was strongly positively correlated with the plant indicator values for mowing tolerance $\left(r_{p}=0.75, P<0.0001\right)$ and soil nutrient content $\left(r_{p}=0.70, P<0.0001\right)$.

\subsection{LUI Map and Variation Partitioning}

Topo-climatic, economic output, and remote-sensing data were suitable for mapping LUI. Model fit and model accuracy were high (Adjusted $\mathrm{D}^{2}=0.652, \mathrm{MAE}=0.132$, $\mathrm{RMSE}=0.187, \mathrm{R}^{2}=0.717$ ).

The LUI map of the entire country (Figure 3a) shows that areas with a high LUI index occur throughout the Central Plateau, which is the main arable farming region. Within this region, particularly high LUI values can be found in central and north-eastern Switzerland, which are major pork-producing regions. This leads to high manure inputs on the fields, meadows, and pastures. The LUI index shows the variable suitability of regions for intensive agriculture (Figure $3 b$ ). Former floodplains along rivers can be more intensively farmed than steeper areas due to better accessibility, soil type, and water availability. Local variations in LUI become visible field by field, showing less intense pastures on steep slopes, intensive agriculture on the sloped fields, and very intensive fields in the plain (Figure 3c).

The variation partitioning analysis showed that topo-climatic variables explain the largest part of the LUI index (individual contribution to deviance explained: 0.26 , significance of contribution estimated by ANOVA: $\mathrm{p}<0.0001$ ), with their individual contributions greatly exceeding remote-sensing variables (individual contribution to deviance explained: 0.02 , significance of contribution estimated by ANOVA: $\mathrm{p}<0.0001$; Figure 4). Despite a significant contribution by the economic output variables (ANOVA: $\mathrm{p}<0.0001$ ), they add the least amount of explanation (individual contribution to deviance explained: 0.01; Figure 4). For all inputs and outputs individually, topo-climatic variables explain the most deviance, while remote sensing explains large parts of pesticide and ploughing inputs. For all inputs and outputs individually, economic output variables also do not add much explanatory power.

Spatial predictions based only on one predictor set showed that topo-climatic variables defined large- to medium-scale patterns of LUI. The highest LUI was in a medium climate on terrain without slope, ridges, or depressions. Economic outputs determined medium-scale patterns with the highest LUI from grazing cattle. Remote sensing revealed local-scale patterns with highest LUI with a high mean and variation in NDVI (Figure 5). 


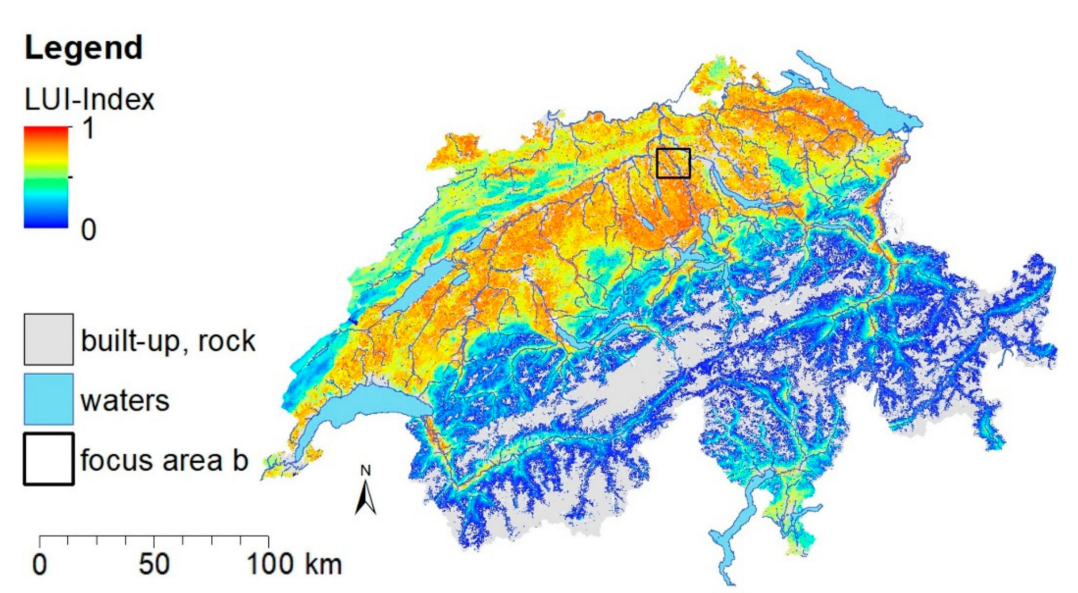

(a)

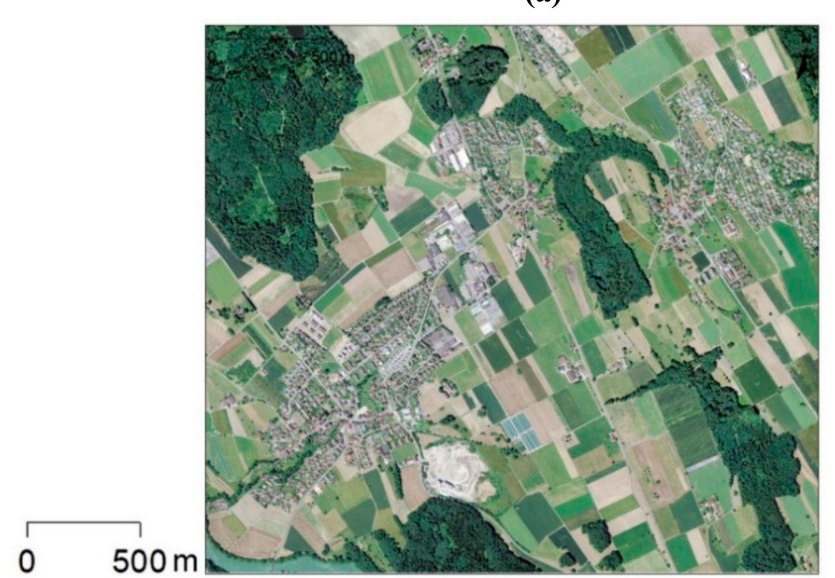

(c-Aerial)
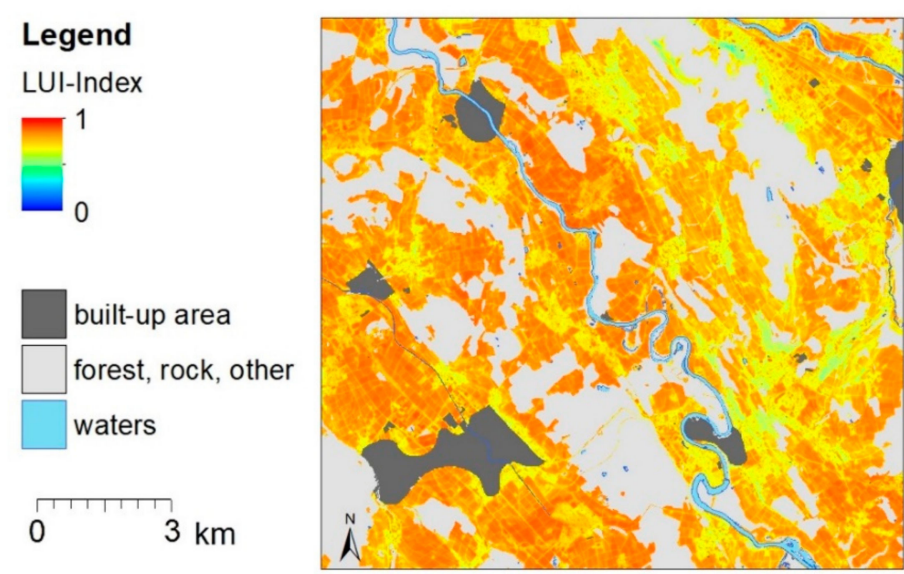

(b)

Legend
LUI-Index
1
0
forest
built-up area
waters
$\square$ gravel pit
$5 \quad 500 \mathrm{~m}$

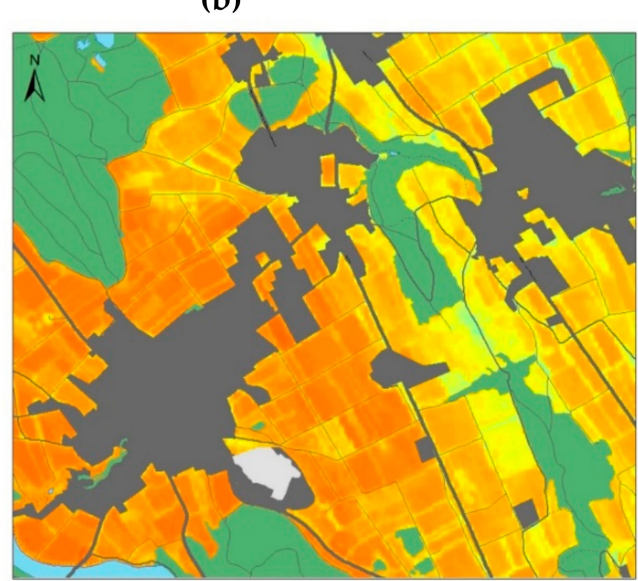

(c)

Figure 3. LUI map for the agricultural area based on the "full model" for the whole of Switzerland (a) and two zoom levels (b,c). (c-Aerial) is an aerial orthoimage of the same area. Settlements, forest, and areas without vegetation are masked in grey, and water bodies are masked in blue. 


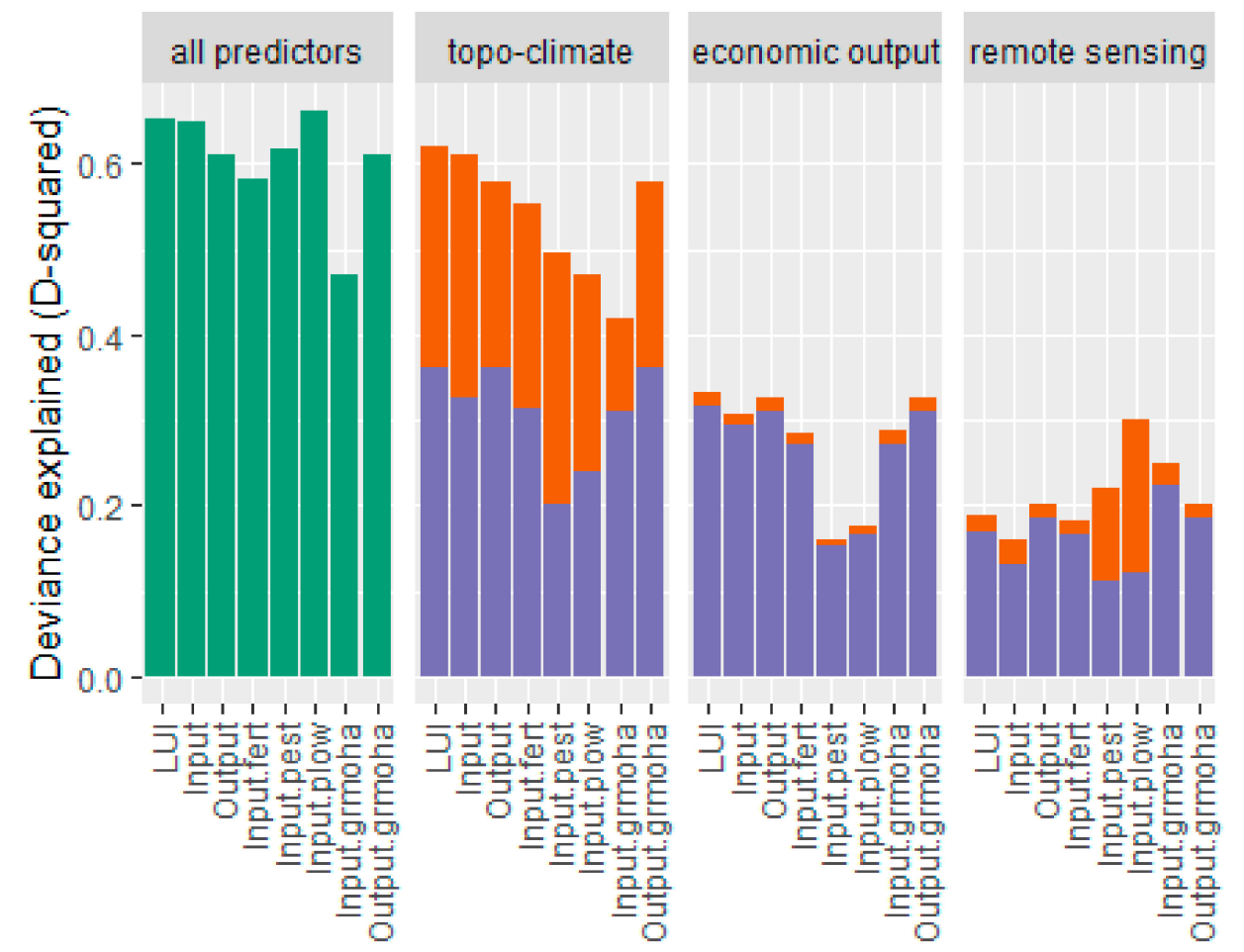

Figure 4. Deviance explained by the full model (green), the individual contribution (orange) and the joint contribution (violet) of the topo-climatic predictors, the economic output predictors, and the remote-sensing predictors, where LUI = LUI index; Input = the input dimension of the LUI; Output = the output dimension of the LUI; Input fert = fertiliser input; Input.pest = pesticide input; Input.plow = ploughing; Input.grmoha = grazing, mowing, and harvesting; and Output.grmoha = biomass output by grazing, mowing, and harvesting. 


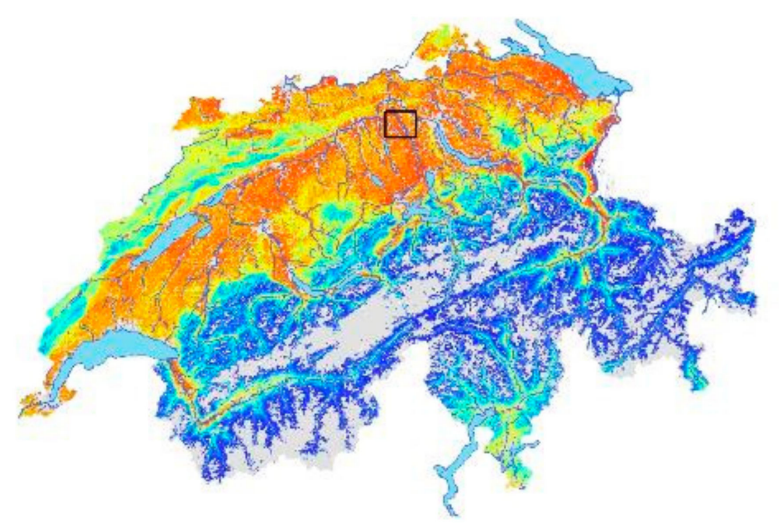

(a)

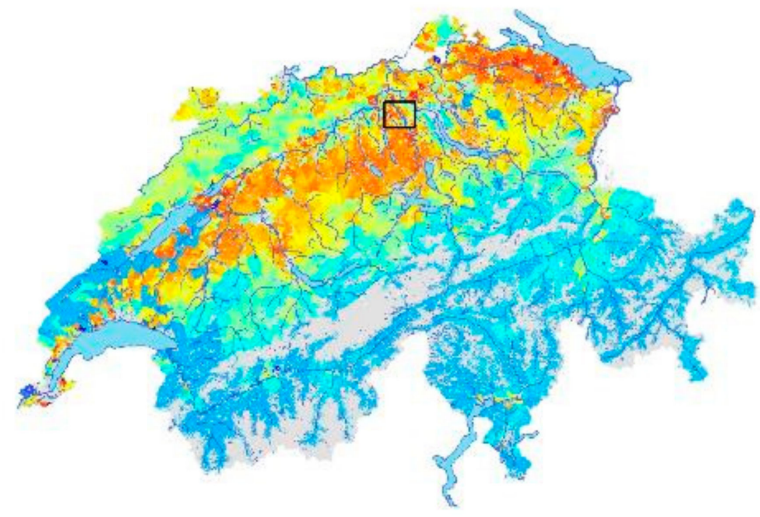

(c)

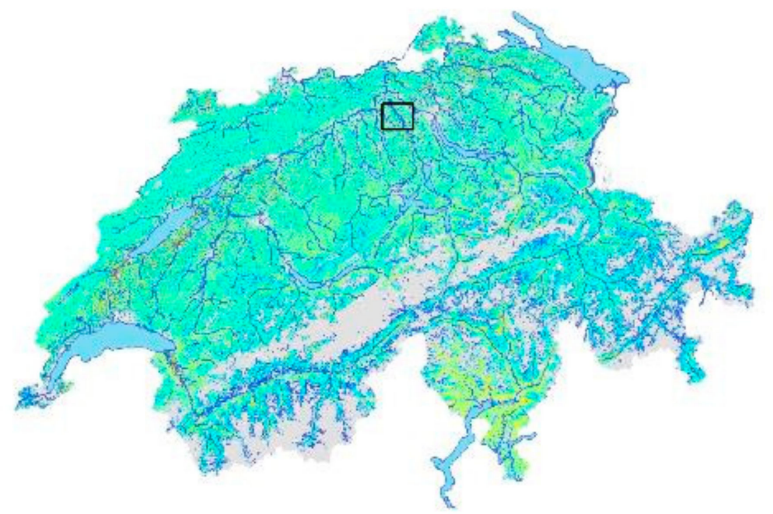

(e)
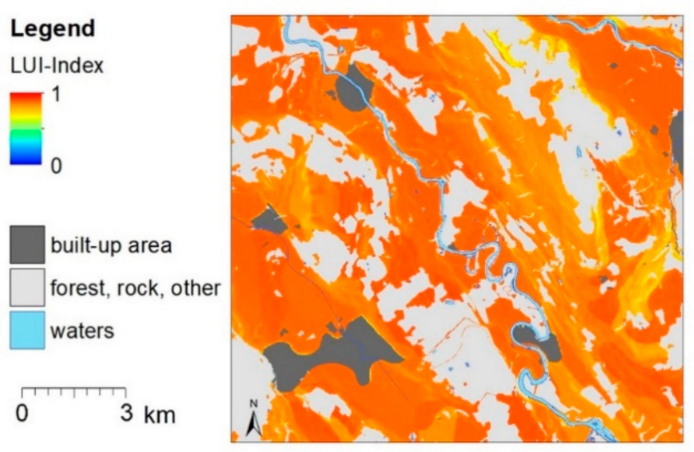

(b)

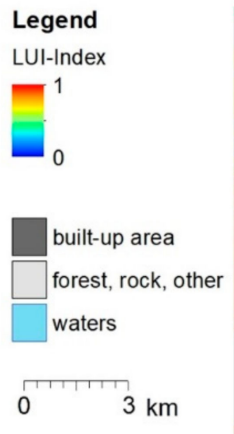

(d)

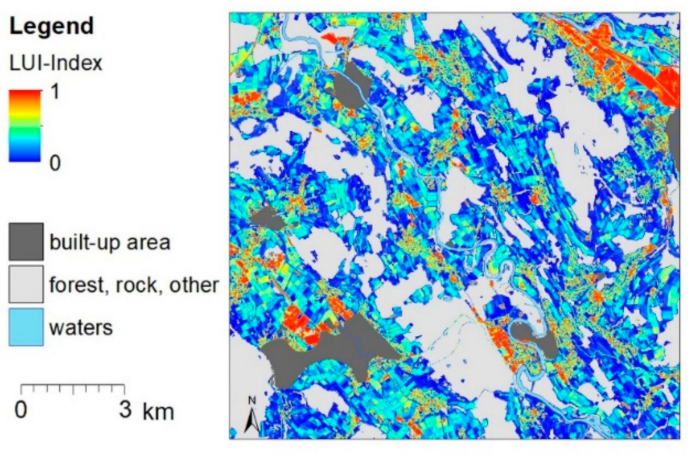

(f)

Figure 5. LUI map based only on (a,b) climate, topography, soil, (c,d) economy, and (e,f) remote-sensing data for Switzerland $(\mathbf{a}, \mathbf{c}, \mathbf{e})$ and the excerpt from zoom level b from Figure $3(\mathbf{b}, \mathbf{d}, \mathbf{f})$.

\section{Discussion}

The failure to address LUI differences between and within land-cover classes has limited the scientists' ability to make credible estimations of future responses of biodiversity to changes in land use and land cover in interaction with climate change $[17,18,32]$. Our results demonstrate the feasibility of using a combination of topo-climatic, economic, and remote-sensing data to map LUI at a fine scale between and within land-cover classes across the agricultural area of Switzerland. Large- to medium-scale patterns of LUI are best explained by biophysical properties (topo-climatic variables), while economic properties (economic output variables) contribute to medium-scale patterns, and the actual local agricultural management (agricultural input and biomass output, constrained by the 
biophysical and economic properties; remote-sensing variables), defines local patterns. To ensure a correct interpretation of our results, we discuss these points critically below.

\subsection{LUI Index Parametrisation and Evaluation}

LUI can be defined by inputs, outputs, and system properties [33]. Here, we addressed these LUI components for each habitat type and condensed them into one LUI index because they are not fully independent of each other [74]. The resulting index enabled the differentiation of LUI within and between land-cover classes, which is needed to better understand changes from interactions of land use, land cover, and climate change [17,18,32]. However, estimates of LUI components (fertiliser input, pesticide input, ploughing, and biomass output) were based on expert ratings rather than quantitative numbers. Moreover, in the LUI index presented here, the components are weighted equally, although their actual contributions may differ. Thus, a better conceptual understanding would be desirable for an improved LUI index. Such an understanding could be fostered by time-series analyses based on remote-sensing data, where fertiliser input, pesticide input, ploughing, grazing, mowing, harvesting, and biomass output could be monitored over the entire season (for fertilisation input, grazing, and mowing see [36]), and then be condensed into a LUI index. Nevertheless, the evaluation of the parametrised LUI index showed that it was strongly positively correlated with aerial nitrogen deposition (which represents ammonia emissions due to mineral fertiliser inputs and aspects of livestock breeding, such as grazing and manure application), the plant cover weighted mean mowing tolerance index, and the plant cover weighted mean soil nutrient content index. This indicates that the LUI index is a suitable representation of LUI.

\subsection{Spatial Predictions of LUI}

Since land-use activities take place in production systems that are defined by their biophysical and socio-economic properties [75], spatially explicit biophysical and socio-economic data could help to map LUI. We showed that it is feasible to map LUI using topo-climatic data, agricultural outputs, and remote-sensing data. Topo-climatic variables determine large to medium-scale patterns; the highest LUI was on medium climate terrain without slope, ridges, or depressions. Economic outputs determined medium-scale patterns with the highest LUI from grazing cattle. Remote sensing revealed local-scale patterns with the highest LUI at a high annual primary production (high average NDVI) and a high number of treatments (high variation in NDVI) [60,62].

\subsection{Importance of Biophysical Factors for LUI}

The variation partitioning analysis showed that topo-climatic variables explain most of the deviation of the LUI index, with their individual contributions greatly exceeding the remote-sensing data and economic output. Thus, the potential LUI predicted by biophysical factors is consistent with actual farming practices. This dominating effect of climate is in line with Holzkämper et al. [76], who showed that climate is a major driver of agricultural production. Similarly, Gerstner et al. [7] found that plant diversity was not additionally affected, and they found that in addition to land-use, environmental, and socio-economic factors had no effect on plant diversity, possibly because LUI itself is already strongly shaped by environmental and economic factors.

\subsection{Suitability of Remote-Sensing Data for LUI Mapping}

Remote-sensing data is already being used for mapping habitats [77], species [78], and biodiversity [25,62,79,80], and is arguably one of the most important technologies available for mapping patterns of current LUI in agricultural systems across broad geographic extents [16,35-38,42]. Nevertheless, current remote-sensing approaches have several shortcomings, and consequently our understanding of the global patterns of LUI is still weak [16]. On the one hand, existing maps have a limited extent, are too coarse, are based on model outputs instead of observations, or represent only snapshots in time that cannot describe highly dynamic land management systems [16,81]. Furthermore, 
current remote-sensing approaches are mostly focused on individual agricultural land-use classes (e.g., field crops [40], grassland [36]) or individual LUI components (e.g., biomass removal [42], grassland mowing frequency [39]). This may be because LUI is a complex and multidimensional phenomenon that needs a strong conceptual framework for its definition [33]. On the other hand, remote-sensing data has not been used in combination with other variables to explain these patterns $[82,83]$. Neglecting topo-climatic and economic output variables may not affect the results for landscapes without large environmental or economic gradients but may strongly bias predictions for more diverse landscapes. Our results show that maps produced only with remote-sensing data had a lower model quality and poorly represented medium- to large-scale patterns compared to maps that also included topo-climatic and economic output data. With our approach, which integrates a methodological framework of LUI, data from remote sensors, and ancillary data, LUI patterns can be well mapped at fine scales across large extents.

\section{Conclusions}

Our LUI index is a suitable representation for LUI, which can be predicted well spatially using topo-climatic, economic output, and remote-sensing predictors. Our methodology can be easily applied to other countries where habitat-type data are available - due to the worldwide availability of remote-sensing and topo-climatic data, these data should hardly represent a shortage. Given the low explanatory power of economic output variables, they may be omitted if not available.

Large- to medium-scale patterns of LUI are explained by topo-climatic predictors, while economic output predictors contribute to explaining medium-scale patterns, and remote-sensing predictors contribute to explaining local-scale patterns. The dominating effect of topo-climatic variables suggests that biophysical factors largely determine farming practices and therefore LUI, or that individual LUI components, in combination with land cover, land use, and climate descriptors, help with conducting detailed analyses of the responses of different organisms and ecosystem functions to changes in these factors. Then, with the knowledge of strong climatic influences on LUI, we may be able to make more credible estimations of the future response of different organisms, biodiversity, and ecosystem functions to land-use and land-cover changes to LUI in interaction with climate change $[17,32]$.

With the gradual fine-scaled LUI map, it is now possible to estimate within unvarying land-use classes the effect on agrobiodiversity by an increase in LUI on fertile and accessible lands and a decrease of LUI by the abandonment of marginal agricultural lands. Further, by including thresholds, landscape configuration metrics, that are needed for instance to estimate edge effects [84] may also be derived from our finely graduated LUI maps. When deriving species-specific metrics from LUI maps, thresholds for natural areas and agricultural land use could be varied to gain a better understanding of the effects of land-use configuration on ecosystem functions.

Author Contributions: Conceptualisation, E.S.M., and A.P.; methodology, E.S.M., A.P., and A.I.; formal analysis, E.S.M., and A.P.; visualisation, E.S.M., and A.I.; writing-original draft preparation, E.S.M., A.P., A.I., and C.G.; writing-review and editing, E.S.M., A.P., and A.I. All authors have read and agreed to the published version of the manuscript.

Acknowledgments: This research was conducted as part of the ALL-EMA project, funded by the Federal Office for the Environment and the Federal Office for Agriculture.

Conflicts of Interest: The authors declare no conflict of interest. The funders had no role in the design of the study; in the collection, analyses, or interpretation of data; in the writing of the manuscript; or in the decision to publish the results. 


\section{Appendix A}

Table A1. Ratings of the land-use intensity factors and the combined LUI index per habitat type. Habitat type headings are underlined.

\begin{tabular}{|c|c|c|c|c|c|c|c|}
\hline $\begin{array}{l}\text { Habitat Type } \\
\text { Code }\end{array}$ & $\begin{array}{l}\text { Habitat Type } \\
\text { Name }\end{array}$ & $\begin{array}{c}\text { Fertiliser } \\
\text { (Input) }\end{array}$ & $\begin{array}{c}\text { Pesticide } \\
\text { (Input) }\end{array}$ & $\begin{array}{l}\text { Ploughing } \\
\text { (Input) }\end{array}$ & $\begin{array}{l}\text { Grazing, Mowing, } \\
\text { Harvest (Input) }\end{array}$ & $\begin{array}{l}\text { Grazing, Mowing, } \\
\text { Harvest (Output) }\end{array}$ & LUI Index \\
\hline 1 & Non-marine waters & & & & & & \\
\hline$\underline{13}$ & Springs & & & & & & \\
\hline$\overline{13 X}$ & $\frac{1}{\text { Springs }}$ & 0 & 0 & 0 & 0 & 0 & 0 \\
\hline 2 & Vegetation of banks and wetlands & & & & & & \\
\hline 20 & Artificial banks & & & & & & \\
\hline$\overline{20 X}$ & $\overline{\text { Artificial banks }}$ & 0 & 0 & 0 & 0 & 0 & 0 \\
\hline$\underline{21}$ & Water fringe vegetation & & & & & & \\
\hline $21 X$ & $\begin{array}{c}\text { Peatmoss-bladderwort bog pools, Northern perennial } \\
\text { amphibious communities, Small reed beds of fast-flowing } \\
\text { waters }(221,223,224)\end{array}$ & 0 & 0 & 0 & 0.2 & 1.6 & 0.017 \\
\hline 212 & Reed beds & 0 & 0 & 0 & 0.4 & 3.2 & 0.033 \\
\hline 22 & Fens and transition mires & & & & & & \\
\hline$\overline{221}$ & $\overline{\text { Large sedge communities }}$ & 0 & 0 & 0 & 0.2 & 0.2 & 0.010 \\
\hline 222 & Acidic fens & 0 & 0 & 0 & 0.5 & 1 & 0.028 \\
\hline 223 & Rich fens & 0 & 0 & 0 & 0.5 & 1 & 0.028 \\
\hline 224 & Transition mires & 0 & 0 & 0 & 0 & 0 & 0.000 \\
\hline 225 & Arcto-alpine riverine swards & 0 & 0 & 0 & 0.2 & 0 & 0.009 \\
\hline$\underline{23}$ & Humid grasslands & & & & & & \\
\hline$\overline{231}$ & Purple moorgrass meadows and related communities & 0 & 0 & 0 & 0.8 & 8 & 0.073 \\
\hline 232 & Atlantic and Sub-Atlantic humid meadows & 0.5 & 0.1 & 0 & 1.5 & 5 & 0.120 \\
\hline 233 & Meadowsweet stands and related communities & 0.5 & 0 & 0 & 1 & 5 & 0.092 \\
\hline$\underline{24}$ & Raised bogs & & & & & & \\
\hline$\overline{241}$ & Bog hummocks, ridges, and lawns & 0 & 0 & 0 & 0 & 0 & 0.000 \\
\hline$\underline{25}$ & Temporarily flooded annual vegetation & & & & & & \\
\hline$\overline{25 x}$ & $\overline{\text { Temporarily flooded annual vegetation }}$ & 0.1 & 0 & 0 & 0.5 & 0 & 0.028 \\
\hline$\underline{3}$ & Glaciers, rocks, screes, and gravel & & & & & & \\
\hline 31 & Eternal snow and ice & & & & & & \\
\hline 314 & Spring snow packs & 0 & 0 & 0 & 0 & 0 & 0 \\
\hline$\underline{32}$ & Alluvial deposits and moraines & & & & & & \\
\hline $32 X$ & $\overline{\text { Alluvial deposits and moraines }}$ & 0 & 0 & 0 & 0 & 0 & 0.000 \\
\hline$\underline{33}$ & Screes & & & & & & \\
\hline $3 \overline{3} x$ & $\overline{\text { Screes }}$ & 0 & 0 & 0 & 0 & 0 & 0 \\
\hline 34 & Inland cliffs and exposed rocks & & & & & & \\
\hline$\overline{34 X}$ & $\overline{\text { Inland cliffs and exposed rocks }}$ & 0 & 0 & 0 & 0 & 0 & 0 \\
\hline
\end{tabular}


Table A1. Cont.

\begin{tabular}{|c|c|c|c|c|c|c|c|}
\hline $\begin{array}{l}\text { Habitat Type } \\
\text { Code }\end{array}$ & $\begin{array}{l}\text { Habitat Type } \\
\text { Name }\end{array}$ & $\begin{array}{c}\text { Fertiliser } \\
\text { (Input) }\end{array}$ & $\begin{array}{c}\text { Pesticide } \\
\text { (Input) }\end{array}$ & $\begin{array}{c}\text { Ploughing } \\
\text { (Input) }\end{array}$ & $\begin{array}{l}\text { Grazing, Mowing, } \\
\text { Harvest (Input) }\end{array}$ & $\begin{array}{l}\text { Grazing, Mowing, } \\
\text { Harvest (Output) }\end{array}$ & LUI Index \\
\hline$\frac{4}{40}$ & Artificial grasslands & & & & & & \\
\hline$\overline{401}$ & Temporarily grasslands in rotated crops & 5 & 0.5 & 0.3 & 5 & 110 & 1.000 \\
\hline 403 & Lowland sowings after earthwork (road slopes...) & 0.2 & 0.1 & 0 & 1 & 30 & 0.197 \\
\hline 404 & High altitude sowings after earthwork (ski slopes...) & 0.2 & 0.1 & 0 & 1 & 20 & 0.151 \\
\hline$\underline{41}$ & Rocky flagstones and limestone pavements & & & & & & \\
\hline$\overline{411}$ & Middle European rock debris swards & 0 & 0 & 0 & 0.1 & 0 & 0.005 \\
\hline 412 & Stepped and garland grasslands & 0 & 0 & 0 & 0 & 0 & 0.000 \\
\hline 413 & Middle European rock debris swards/Pavements & 0 & 0 & 0 & 0.1 & 0 & 0.005 \\
\hline 414 & Alpine weathered rock and outcrop communities/Pavements & 0 & 0 & 0 & 0 & 0 & 0.000 \\
\hline$\underline{42}$ & Thermophilus dry grasslands & & & & & & \\
\hline$\overline{421}$ & Sub-Continental steppic grasslands & 0 & 0 & 0 & 0.8 & 2 & 0.048 \\
\hline 422 & Sub-Atlantic very dry calcareous grasslands & 0.1 & 0 & 0 & 0.8 & 3 & 0.056 \\
\hline 423 & Insubrian Mesobromion grasslands & 0 & 0 & 0 & 1 & 5 & 0.069 \\
\hline 424 & Sub-Atlantic semi-dry calcareous grasslands & 0.1 & 0.1 & 0 & 2 & 15 & 0.170 \\
\hline$\underline{43}$ & $\underline{\text { Unfertilised mountain grasslands and pastures }}$ & & & & & & \\
\hline$\overline{431}$ & Blue moorgrass-evergreen sedge slopes & 0 & 0 & 0 & 0.5 & 4 & 0.041 \\
\hline 432 & Cushion sedge carpets & 0 & 0 & 0 & 0.3 & 0 & 0.015 \\
\hline 433 & Northern rusty sedge grasslands & 0 & 0 & 0 & 0.5 & 4 & 0.041 \\
\hline 434 & Wind edge naked-rush swards & 0 & 0 & 0 & 0.2 & 0 & 0.009 \\
\hline 435 & Mat-grass swards and related communities & 0.1 & 0 & 0 & 1 & 8 & 0.087 \\
\hline 436 & Subalpine thermophile siliceous grasslands & 0 & 0 & 0 & 0 & 0 & 0.000 \\
\hline 437 & Crooked-sedge swards and related communities & 0 & 0 & 0 & 0.5 & 1 & 0.025 \\
\hline 44 & Snow-patches & & & & & & \\
\hline$\overline{44 X}$ & $\overline{\text { Snow-patches }}$ & 0 & 0 & 0 & 0.1 & 0 & 0.005 \\
\hline$\underline{45}$ & $\underline{\text { Fertilised grasslands }}$ & & & & & & \\
\hline 451_LD & Medio-European lowland hay meadows (low diversity) & 4 & 0.5 & 0 & 4 & 100 & 0.848 \\
\hline 451_MD & Medio-European lowland hay meadows (medium diversity) & 2 & 0.1 & 0 & 2.5 & 80 & 0.577 \\
\hline 451_HD & Medio-European lowland hay meadows (high diversity) & 0.5 & 0.1 & 0 & 2 & 70 & 0.439 \\
\hline 452_LD & Mountain and subalpine hay meadows (low diversity) & 2 & 0.1 & 0 & 2.7 & 60 & 0.495 \\
\hline 452_MD & Mountain and subalpine hay meadows (medium diversity) & 1.5 & 0.1 & 0 & 1.8 & 35 & 0.316 \\
\hline 452_HD & Mountain and subalpine hay meadows (high diversity) & 1 & 0.1 & 0 & 1.2 & 25 & 0.220 \\
\hline 453_LD & Mesophilic pastures (low diversity) & 3 & 0.2 & 0 & 4 & 100 & 0.788 \\
\hline 453_MD & Mesophilic pastures (medium diversity) & 2 & 0.5 & 0 & 2.5 & 85 & 0.618 \\
\hline 453_HD & Mesophilic pastures (high diversity) & 0.5 & 0.1 & 0 & 1.5 & 50 & 0.324 \\
\hline 454_LD & Rough hawkbit pastures (low diversity) & 0.5 & 0.1 & 0 & 2 & 75 & 0.461 \\
\hline 454_MD & Rough hawkbit pastures (medium diversity) & 0.2 & 0 & 0 & 1 & 35 & 0.215 \\
\hline 454_HD & Rough hawkbit pastures (high diversity) & 0.1 & 0 & 0 & 1 & 25 & 0.165 \\
\hline
\end{tabular}


Table A1. Cont.

\begin{tabular}{|c|c|c|c|c|c|c|c|}
\hline $\begin{array}{l}\text { Habitat Type } \\
\text { Code }\end{array}$ & $\begin{array}{l}\text { Habitat Type } \\
\text { Name }\end{array}$ & $\begin{array}{c}\text { Fertiliser } \\
\text { (Input) }\end{array}$ & $\begin{array}{c}\text { Pesticide } \\
\text { (Input) }\end{array}$ & $\begin{array}{l}\text { Ploughing } \\
\text { (Input) }\end{array}$ & $\begin{array}{l}\text { Grazing, Mowing, } \\
\text { Harvest (Input) }\end{array}$ & $\begin{array}{l}\text { Grazing, Mowing, } \\
\text { Harvest (Output) }\end{array}$ & LUI Index \\
\hline 46 & Abandoned grasslands & & & & & & \\
\hline$\overline{461}$ & Abandoned grasslands with Agropyron repens & 0 & 0.2 & 0 & 0.2 & 1 & 0.023 \\
\hline $46 \mathrm{X}$ & $\begin{array}{l}\text { Abandoned grasslands with Brachypodium pinnatum, } \\
\text { Arrhenatherum elatius, Molinia arundinacea, or Calamagrostis varia }\end{array}$ & 0 & 0.2 & 0 & 0.5 & 2 & 0.041 \\
\hline$\underline{5}$ & Woodland edges, tall herbs communities, scrubs & & & & & & \\
\hline$\overline{51}$ & Fringes & & & & & & \\
\hline 511 & Xero-thermophile fringes & 0.2 & 0.1 & 0 & 0.5 & 1 & 0.039 \\
\hline 512 & Mesophilic fringes & 0.2 & 0.1 & 0 & 0.5 & 2 & 0.044 \\
\hline 513 & Mixed riverine screens & 0.1 & 0.1 & 0 & 0.2 & 1 & 0.021 \\
\hline 514 & Butterbur riverine communities & 0 & 0 & 0 & 0.1 & 0 & 0.006 \\
\hline 515 & Shady woodland edge fringes & 0.1 & 0.1 & 0 & 1 & 3 & 0.069 \\
\hline$\underline{52}$ & Clearings & & & & & & \\
\hline $52 X$ & $\begin{array}{l}\text { Burdock and deadly nightshade clearings, Willowherb and } \\
\text { foxglove clearings }(521,522)\end{array}$ & 0 & 0 & 0 & 0.2 & 0 & 0.010 \\
\hline 523 & Subalpine small reed meadows & 0 & 0 & 0 & 0.2 & 1 & 0.014 \\
\hline 524 & Hercynio-alpine tall herb communities & 0 & 0 & 0 & 0.2 & 0 & 0.011 \\
\hline 525 & Bracken fields & 0.1 & 0.1 & 0 & 0.2 & 2 & 0.026 \\
\hline$\underline{53}$ & $\underline{\text { Scrubs, brushes, and clearings }}$ & & & & & & \\
\hline$\overline{530}$ & Artificial hedgerows & 0.1 & 0.1 & 0 & 0 & 0 & 0.009 \\
\hline 531 & Medio-European Cytisus scoparius fields & 0 & 0 & 0 & 0.5 & 2 & 0.032 \\
\hline 532 & Blackthorn-privet scrub and box thickets & 0 & 0 & 0 & 0.5 & 1 & 0.028 \\
\hline 533 & Blackthorn-bramble scrub & 0 & 0 & 0 & 0.1 & 0 & 0.006 \\
\hline 534 & Bramble scrubs & 0.1 & 0.1 & 0 & 0.1 & 0 & 0.015 \\
\hline 535 & Shrubby clearings & 0 & 0 & 0 & 0 & 0 & 0.000 \\
\hline 536 & Pre-Alpine Willow brush & 0 & 0 & 0 & 0.5 & 0 & 0.023 \\
\hline 537 & Mire Willow scrub & 0 & 0 & 0 & 0 & 0 & 0.000 \\
\hline 538 & Willow brush & 0 & 0 & 0 & 0.1 & 0 & 0.005 \\
\hline 539 & Alpine green alder scrub & 0 & 0 & 0 & 0.1 & 0 & 0.005 \\
\hline$\underline{54}$ & Dry heaths & & & & & & \\
\hline 541 & Sub-Atlantic acidophilous heaths & 0 & 0 & 0 & 0.5 & 1 & 0.025 \\
\hline 542 & Juniperus sabina scrub & 0 & 0 & 0 & 0.2 & 0 & 0.010 \\
\hline 543 & Bearberry and hairy alpenrose heaths & 0 & 0 & 0 & 0 & 0 & 0.000 \\
\hline 544 & Juniperus nana scrub & 0 & 0 & 0 & 0.5 & 1 & 0.025 \\
\hline 545 & Alpenrose heaths & 0 & 0 & 0 & 0.5 & 1 & 0.025 \\
\hline 546 & Dwarf Azalea and Vaccinium heaths & 0 & 0 & 0 & 0.1 & 0 & 0.005 \\
\hline$\underline{6}$ & Forests & & & & & & \\
\hline$\overline{6 x}$ & $\overline{\text { Forests }}$ & & & & & & \\
\hline$\overline{6 X X}$ & $\overline{\text { Forests }}$ & 0 & 0 & 0 & 0.5 & 1 & 0.028 \\
\hline
\end{tabular}


Table A1. Cont.

\begin{tabular}{|c|c|c|c|c|c|c|c|}
\hline $\begin{array}{l}\text { Habitat Type } \\
\text { Code }\end{array}$ & $\begin{array}{l}\text { Habitat Type } \\
\text { Name }\end{array}$ & $\begin{array}{l}\text { Fertiliser } \\
\text { (Input) }\end{array}$ & $\begin{array}{c}\text { Pesticide } \\
\text { (Input) }\end{array}$ & $\begin{array}{l}\text { Ploughing } \\
\text { (Input) }\end{array}$ & $\begin{array}{l}\text { Grazing, Mowing, } \\
\text { Harvest (Input) }\end{array}$ & $\begin{array}{l}\text { Grazing, Mowing, } \\
\text { Harvest (Output) }\end{array}$ & LUI Index \\
\hline$\underline{7}$ & Pioneer vegetation of disturbed areas (ruderal vegetation) & & & & & & \\
\hline$\underline{71}$ & Trampled and ruderal areas & & & & & & \\
\hline 710 & Trampled ground and unvegetated ruins or debris & 1 & 0.1 & 0.1 & 0 & 0 & 0.056 \\
\hline 711 & Flood swards and related communities & 1 & 0.1 & 0.1 & 3 & 2 & 0.204 \\
\hline 712 & Lowland fallow fields & 1 & 0.1 & 0.1 & 3 & 2 & 0.204 \\
\hline 713 & Subalpine and Alpine fallow fields & 1 & 0 & 0 & 2 & 30 & 0.275 \\
\hline 714 & Annual ruderal vegetation & 0.2 & 0.1 & 0.5 & 0 & 0 & 0.037 \\
\hline 715 & Pluriannual thermophilus ruderal vegetation & 0.1 & 0 & 0.2 & 0.2 & 0 & 0.025 \\
\hline 716 & Pluriannual mesophilic ruderal vegetation & 0.1 & 0.1 & 0.2 & 0 & 0 & 0.019 \\
\hline 717 & Alpine dock communities & 1 & 0.1 & 0 & 1 & 10 & 0.143 \\
\hline 718 & Lowland dock communities & 0.1 & 0 & 0.1 & 0.2 & 0 & 0.020 \\
\hline$\underline{72}$ & Anthropogenic rocky habitats & & & & & & \\
\hline 720 & Unvegetated walls or paved areas & 0 & 0.2 & 0 & 0 & 0 & 0.009 \\
\hline 721 & Vegetated ruins or old walls & 0 & 0.1 & 0 & 0 & 0 & 0.005 \\
\hline 722 & Vegetated paved areas & 0 & 1 & 0 & 0 & 0 & 0.046 \\
\hline$\underline{8}$ & Plantations, fields, and cropland & & & & & & \\
\hline$\underline{81}$ & $\overline{\text { Cultivated ligneous formations }}$ & & & & & & \\
\hline $81 X$ & $\begin{array}{l}\text { Deciduous seedbeds, Coniferous seedbeds, Chestnut groves } \\
\text { (without undergrowth), High stem orchard }\end{array}$ & 0.1 & 4 & 0.1 & 1.1 & 5 & 0.268 \\
\hline 815 & Low-stem orchard & 2 & 5 & 0.2 & 1.1 & 5 & 0.407 \\
\hline 816 & Vineyards & 2 & 5 & 0.3 & 0.6 & 2 & 0.377 \\
\hline 817 & Small fruits & 3 & 3 & 0.5 & 0.5 & 3 & 0.335 \\
\hline$\underline{82}$ & Field crops & & & & & & \\
\hline 82X_LD & Field crops (low diversity) & 3 & 3 & 1.5 & 2 & 100 & 0.894 \\
\hline 82X_MD & Field crops (medium diversity) & 2 & 2 & 1.5 & 2 & 100 & 0.802 \\
\hline 82X_HD & Field crops (high diversity) & 1.5 & 1.5 & 1.5 & 1.5 & 100 & 0.732 \\
\hline
\end{tabular}




\section{References}

1. Godfray, H.C.J.; Beddington, J.R.; Crute, I.R.; Haddad, L.; Lawrence, D.; Muir, J.F.; Pretty, J.; Robinson, S.; Thomas, S.M.; Toulmin, C. Food security: The challenge of feeding 9 billion people. Science 2010, 327, 812-818. [CrossRef] [PubMed]

2. Meehan, T.D.; Werling, B.P.; Landis, D.A.; Gratton, C. Agricultural landscape simplification and insecticide use in the Midwestern United States. Proc. Natl. Acad. Sci. USA 2011, 108, 11500-11505. [CrossRef]

3. Pe'er, G.; Dicks, L.V.; Visconti, P.; Arlettaz, R.; Báldi, A.; Benton, T.G.; Collins, S.; Dieterich, M.; Gregory, R.D.; Hartig, F.; et al. EU agricultural reform fails on biodiversity. Science 2014, 344, 1090-1092. [CrossRef] [PubMed]

4. Titeux, N.; Henle, K.; Mihoub, J.-B.; Brotons, L. Climate change distracts us from equally important threats to biodiversity. Front. Ecol. Environ. 2016, 14, 291. [CrossRef]

5. Newbold, T.; Hudson, L.N.; Hill, S.L.L.; Contu, S.; Lysenko, I.; Senior, R.A.; Borger, L.; Bennett, D.J.; Choimes, A.; Collen, B.; et al. Global effects of land use on local terrestrial biodiversity. Nature 2015, 520, 45-50. [CrossRef]

6. Fahrig, L. Rethinking patch size and isolation effects: The habitat amount hypothesis. J. Biogeogr. 2013, 40, 1649-1663. [CrossRef]

7. Gerstner, K.; Dormann, C.F.; Stein, A.; Manceur, A.M.; Seppelt, R. Effects of land use on plant diversity-A global meta-analysis. J. Appl. Ecol. 2014, 51, 1690-1700. [CrossRef]

8. Seppelt, R.; Beckmann, M.; Ceauşu, S.; Cord, A.F.; Gerstner, K.; Gurevitch, J.; Kambach, S.; Klotz, S.; Mendenhall, C.; Phillips, H.R.P.; et al. Harmonizing biodiversity conservation and productivity in the context of increasing demands on landscapes. Bioscience 2016, 66, 890-896. [CrossRef]

9. Foley, J.A.; Ramankutty, N.; Brauman, K.A.; Cassidy, E.S.; Gerber, J.S.; Johnston, M.; Mueller, N.D.; O'Connell, C.; Ray, D.K.; West, P.C.; et al. Solutions for a cultivated planet. Nature 2011, 478, 337-342. [CrossRef]

10. MacDonald, D.; Crabtree, J.R.; Wiesinger, G.; Dax, T.; Stamou, N.; Fleury, P.; Gutierrez Lazpita, J.; Gibon, A. Agricultural abandonment in mountain areas of Europe: Environmental consequences and policy response. J. Environ. Manag. 2000, 59, 47-69. [CrossRef]

11. Stoate, C.; Boatman, N.D.; Borralho, R.J.; Carvalho, C.R.; De Snoo, G.R.; Eden, P. Ecological impacts of arable intensification in Europe. J. Environ. Manag. 2001, 63, 337-365. [CrossRef] [PubMed]

12. Benton, T.G.; Vickery, J.A.; Wilson, J.D. Farmland biodiversity: Is habitat heterogeneity the key? Trends Ecol. Evol. 2003, 18, 182-188. [CrossRef]

13. Pereira, H.M.; Navarro, L.M.; Martins, I.S. Global Biodiversity Change: The Bad, the Good, and the Unknown. Annu. Rev. Environ. Resour. 2012, 37, 25-50. [CrossRef]

14. Tasser, E.; Walde, J.; Tappeiner, U.; Teutsch, A.; Noggler, W. Land-use changes and natural reforestation in the Eastern Central Alps. Agric. Ecosyst. Environ. 2007, 118, 115-129. [CrossRef]

15. Kolecka, N.; Kozak, J.; Kaim, D.; Dobosz, M.; Ginzler, C.; Psomas, A. Mapping secondary forest succession on abandoned agricultural land with LiDAR point clouds and terrestrial photography. Remote Sens. 2015, 7, 8300-8322. [CrossRef]

16. Kuemmerle, T.; Erb, K.; Meyfroidt, P.; Müller, D.; Verburg, P.H.; Estel, S.; Haberl, H.; Hostert, P.; Jepsen, M.R.; Kastner, T.; et al. Challenges and opportunities in mapping land use intensity globally. Curr. Opin. Environ. Sustain. 2013, 5, 484-493. [CrossRef]

17. De Chazal, J.; Rounsevell, M.D.A. Land-use and climate change within assessments of biodiversity change: A review. Glob. Environ. Chang. 2009, 19, 306-315. [CrossRef]

18. Stürck, J.; Levers, C.; Van der Zanden, E.H.; Schulp, C.J.E.; Verkerk, P.J.; Kuemmerle, T.; Helming, J.; Lotze-Campen, H.; Tabeau, A.; Popp, A.; et al. Simulating and delineating future land change trajectories across Europe. Reg. Environ. Chang. 2018, 18, 733-749. [CrossRef]

19. Moser, D.; Dullinger, S.; Mang, T.; Hülber, K.; Essl, F.; Frank, T.; Hulme, P.E.; Grabherr, G.; Pascher, K. Changes in plant life-form, pollination syndrome and breeding system at a regional scale promoted by land use intensity. Divers. Distrib. 2015, 21, 1319-1328. [CrossRef]

20. Rüdisser, J.; Tasser, E.; Tappeiner, U. Distance to nature-A new biodiversity relevant environmental indicator set at the landscape level. Ecol. Indic. 2012, 15, 208-216. [CrossRef] 
21. Rüdisser, J.; Walde, J.; Tasser, E.; Frühauf, J.; Teufelbauer, N.; Tappeiner, U. Biodiversity in cultural landscapes: Influence of land use intensity on bird assemblages. Landsc. Ecol. 2015, 30, 1851-1863. [CrossRef]

22. Kovács-Hostyánszki, A.; Földesi, R.; Mózes, E.; Szirák, Á.; Fischer, J.; Hanspach, J.; Báldi, A. Conservation of pollinators in traditional agricultural landscapes-New challenges in Transylvania (Romania) posed by EU accession and recommendations for future research. PLoS ONE 2016, 11, e0151650. [CrossRef] [PubMed]

23. Herzog, F.; Steiner, B.; Bailey, D.; Baudry, J.; Billeter, R.; Bukácek, R.; De Blust, G.; De Cock, R.; Dirksen, J.; Dormann, C.F.; et al. Assessing the intensity of temperate European agriculture at the landscape scale. Eur. J. Agron. 2006, 24, 165-181. [CrossRef]

24. Tuck, S.L.; Winqvist, C.; Mota, F.; Ahnström, J.; Turnbull, L.A.; Bengtsson, J. Land-use intensity and the effects of organic farming on biodiversity: A hierarchical meta-analysis. J. Appl. Ecol. 2014, 51, 746-755. [CrossRef]

25. Rhodes, C.J.; Henrys, P.; Siriwardena, G.M.; Whittingham, M.J.; Norton, L.R. The relative value of field survey and remote sensing for biodiversity assessment. Methods Ecol. Evol. 2015, 6, 772-781. [CrossRef]

26. Pereira, H.M.; Daily, G.C. Modeling biodiversity dynamics in countryside landscapes. Ecology 2006, 87, 1877-1885. [CrossRef]

27. Koh, L.P.; Ghazoul, J. A matrix-calibrated species-area model for predicting biodiversity losses due to land-use change. Conserv. Biol. 2010, 24, 994-1001. [CrossRef]

28. Prugh, L.R.; Hodges, K.E.; Sinclair, A.R.E.; Brashares, J.S. Effect of habitat area and isolation on fragmented animal populations. Proc. Natl. Acad. Sci. USA 2008, 105, 20770-20775. [CrossRef]

29. Revilla, E.; Wiegand, T.; Palomares, F.; Ferreras, P.; Delibes, M. Effects of matrix heterogeneity on animal dispersal: From individual behavior to metapopulation-level parameters. Am. Nat. 2004, 164, E130-E153. [CrossRef]

30. Bender, D.J.; Fahrig, L. Matrix structure obscures the relationship between interpatch movement and patch size and isolation. Ecology 2005, 86, 1023-1033. [CrossRef]

31. Tubelis, D.P.; Lindenmayer, D.B.; Cowling, A. Bird populations in native forest patches in south-eastern Australia: The roles of patch width, matrix type (age) and matrix use. Landsc. Ecol. 2007, 22, 1045-1058. [CrossRef]

32. Harfoot, M.B.J.J.; Newbold, T.; Tittensor, D.P.; Emmott, S.; Hutton, J.; Lyutsarev, V.; Smith, M.J.; Scharlemann, J.P.W.W.; Purves, D.W. Emergent global patterns of ecosystem structure and function from a mechanistic general ecosystem model. PLoS Biol. 2014, 12, 1-24. [CrossRef] [PubMed]

33. Erb, K.-H.; Haberl, H.; Jepsen, M.R.; Kuemmerle, T.; Lindner, M.; Müller, D.; Verburg, P.H.; Reenberg, A. A conceptual framework for analysing and measuring land-use intensity. Curr. Opin. Environ. Sustain. 2013, 5 , 464-470. [CrossRef]

34. Busch, V.; Klaus, V.H.; Schäfer, D.; Prati, D.; Boch, S.; Müller, J.; Chisté, M.; Mody, K.; Blüthgen, N.; Fischer, M.; et al. Will I stay or will I go? Plant species-specific response and tolerance to high land-use intensity in temperate grassland ecosystems. J. Veg. Sci. 2019, 30, 674-686. [CrossRef]

35. Estel, S.; Kuemmerle, T.; Levers, C.; Baumann, M.; Hostert, P. Mapping cropland-use intensity across Europe using MODIS NDVI time series. Environ. Res. Lett. 2016, 11, 024015. [CrossRef]

36. Gómez Giménez, M.; De Jong, R.; Della Peruta, R.; Keller, A.; Schaepman, M.E. Determination of grassland use intensity based on multi-temporal remote sensing data and ecological indicators. Remote Sens. Environ. 2017, 198, 126-139. [CrossRef]

37. Estel, S.; Kuemmerle, T.; Alcántara, C.; Levers, C.; Prishchepov, A.; Hostert, P. Mapping farmland abandonment and recultivation across Europe using MODIS NDVI time series. Remote Sens. Environ. 2015, 163, 312-325. [CrossRef]

38. Griffiths, P.; Nendel, C.; Pickert, J.; Hostert, P. Towards national-scale characterization of grassland use intensity from integrated Sentinel-2 and Landsat time series. Remote Sens. Environ. 2020, 238, 111124. [CrossRef]

39. Kolecka, N.; Ginzler, C.; Pazur, R.; Price, B.; Verburg, P.H. Regional scale mapping of grassland mowing frequency with Sentinel-2 time series. Remote Sens. 2018, 10, 1221. [CrossRef]

40. Veloso, A.; Mermoz, S.; Bouvet, A.; Le Toan, T.; Planells, M.; Dejoux, J.F.; Ceschia, E. Understanding the temporal behavior of crops using Sentinel-1 and Sentinel-2-like data for agricultural applications. Remote Sens. Environ. 2017, 199, 415-426. [CrossRef]

41. Denize, J.; Hubert-Moy, L.; Betbeder, J.; Corgne, S.; Baudry, J.; Pottier, E. Evaluation of using sentinel-1 and -2 time-series to identify winter land use in agricultural landscapes. Remote Sens. 2019, 11, 37. [CrossRef] 
42. Howison, R.A.; Piersma, T.; Kentie, R.; Hooijmeijer, J.C.E.W.; Olff, H. Quantifying landscape-level land-use intensity patterns through radar-based remote sensing. J. Appl. Ecol. 2018, 55, 1276-1287. [CrossRef]

43. Verburg, P.H.; Overmars, K.P. Combining top-down and bottom-up dynamics in land use modeling: Exploring the future of abandoned farmlands in Europe with the Dyna-CLUE model. Landsc. Ecol. 2009, 24, 1167. [CrossRef]

44. Allan, E.; Manning, P.; Alt, F.; Binkenstein, J.; Blaser, S.; Blüthgen, N.; Böhm, S.; Grassein, F.; Hölzel, N.; Klaus, V.H.; et al. Land use intensification alters ecosystem multifunctionality via loss of biodiversity and changes to functional composition. Ecol. Lett. 2015, 18, 834-843. [CrossRef]

45. Allan, E.; Bossdorf, O.; Dormann, C.F.; Prati, D.; Gossner, M.M.; Tscharntke, T.; Bluthgen, N.; Bellach, M.; Birkhofer, K.; Boch, S.; et al. Interannual variation in land-use intensity enhances grassland multidiversity. Proc. Natl. Acad. Sci. USA 2014, 111, 308-313. [CrossRef]

46. Bernhardt-Römermann, M.; Römermann, C.; Sperlich, S.; Schmidt, W. Explaining grassland biomass-The contribution of climate, species and functional diversity depends on fertilization and mowing frequency. $J$. Appl. Ecol. 2011, 48, 1088-1097. [CrossRef]

47. Landolt, E.; Bäumler, B.; Erhardt, A.; Hegg, O.; Klötzli, F.; Lämmler, W.; Nobis, M.; Rudmann-Maurer, K.; Schweingruber, F.H.; Theurillat, J.P. Flora Indicativa-Ökologische Zeigerwerte und Biologische Kennzeichen zur Flora der Schweiz und der Alpen; Haupt: Bern, Switzerland, 2010.

48. Braun-Blanquet, J. Pflanzensoziologie, Grundzüge der Vegetationskunde; Springer: Wien, Austria, 1964.

49. Naimi, B.; Araújo, M.B. Sdm: A reproducible and extensible R platform for species distribution modelling. Ecography 2016, 39, 368-375. [CrossRef]

50. Neter, J.; Wasserman, W.; Kutner, M. Applied Linear Regression Models; Irwin, Inc.: Homewood, IL, USA, 1983.

51. Chatterjee, S.; Hadi, A.S. Regression Analysis by Example; John Wiley \& Sons: Hoboken, NJ, USA, 2006.

52. R Core Team. R: A language and environment for statistical computing. R Foundation for Statistical Computing, Vienna, Austria. Available online: https://www.R-project.org/ (accessed on 1 July 2019).

53. ESRI. ArcGIS Desctop: Release 10.7.1; Environmental Systems Research Institute: Redlands, CA, USA, 2019.

54. Swisstopo. DHM25-Das Digitale Hoehenmodell der Schweiz [DHM25-Digital Terrain Model of Switzerland]. 2005. Available online: https://shop.swisstopo.admin.ch/en/products/height_models/dhm25 (accessed on 30 January 2019).

55. Hijmans, R.J.; Cameron, S.E.; Parra, J.L.; Jones, P.G.; Jarvis, A. Very high resolution interpolated climate surfaces for global land areas. Int. J. Climatol. 2005, 25, 1965-1978. [CrossRef]

56. Zimmermann, N.E.; Kienast, F. Predictive mapping of alpine grasslands in Switzerland: Species versus community approach. J. Veg. Sci. 1999, 10, 469-482. [CrossRef]

57. Guisan, A.; Zimmermann, N.E.N.E.; Elith, J.; Graham, C.H.; Phillips, S.; Peterson, A.T. What matters for predicting the occurrences of trees: Techniques, data, or species' characteristics? Ecol. Monogr. 2007, 77, 615-630. [CrossRef]

58. BFS and BLW. BEK200: Bodeneignungskarte der Schweiz 1:200'000 [BEK200: Soil suitability map of Switzerland]. 2000. Available online: https://www.blw.admin.ch/blw/de/home/politik/datenmanagement/ geografisches-informationssystem-gis/download-geodaten.html (accessed on 30 January 2019).

59. BLW. Agrarpolitisches Informationssystem AGIS. Available online: https://www.blw.admin.ch/blw/de/home/ politik/datenmanagement/agate/agis.html (accessed on 30 January 2019).

60. Alcaraz-Segura, D.; Lomba, A.; Sousa-Silva, R.; Nieto-Lugilde, D.; Alves, P.; Georges, D.; Vicente, J.R.; Honrado, J.P. Potential of satellite-derived ecosystem functional attributes to anticipate species range shifts. Int. J. Appl. Earth Obs. Geoinf. 2017, 57, 86-92. [CrossRef]

61. Pettorelli, N.; Vik, J.O.; Mysterud, A.; Gaillard, J.M.; Tucker, C.J.; Stenseth, N.C. Using the satellite-derived NDVI to assess ecological responses to environmental change. Trends Ecol. Evol. 2005, 20, 503-510. [CrossRef] [PubMed]

62. Pettorelli, N.; Wegmann, M.; Skidmore, A.; Mücher, S.; Dawson, T.P.; Fernandez, M.; Lucas, R.; Schaepman, M.E.; Wang, T.; O'Connor, B.; et al. Framing the concept of satellite remote sensing essential biodiversity variables: Challenges and future directions. Remote Sens. Ecol. Conserv. 2016, 2, 122-131. [CrossRef]

63. Rihm, B.; Achermann, B. Critical loads of nitrogen and their exceedances. Swiss contribution to the effects-oriented work under the convention on long-range transboundary air pollution (UNECE). FOEN Environ. Stud. 2016, 1642, 78. 
64. Thornton, P.E.; Running, S.W.; White, M.A. Generating surfaces of daily meteorological variables over large regions of complex terrain. J. Hydrol. 1997, 190, 214-251. [CrossRef]

65. Delarze, R.; Gonseth, Y. Lebensräume der Schweiz: Ökologie, Gefährdung, Kennarten; Ott Verlag: Thun, Switzerland, 2008; Volume 2.

66. Blüthgen, N.; Dormann, C.F.; Prati, D.; Klaus, V.H.; Kleinebecker, T.; Hölzel, N.; Alt, F.; Boch, S.; Gockel, S.; Hemp, A.; et al. A quantitative index of land-use intensity in grasslands: Integrating mowing, grazing and fertilization. Basic Appl. Ecol. 2012, 13, 207-220. [CrossRef]

67. Weisberg, S. Applied Linear Regression; Wiley: New York, NY, USA, 1980, ISBN 0-471-04419-9.

68. Guisan, A.; Zimmermann, N.E. Predictive habitat distribution models in ecology. Ecol. Modell. 2000, 135, 147-186. [CrossRef]

69. Zhang, D. A coefficient of determination for generalized linear models. Am. Stat. 2017, 71, 310-316. [CrossRef]

70. Voltz, M.; Webster, R. A comparison of kriging, cubic splines and classification for predicting soil properties from sample information. J. Soil Sci. 1990, 41, 473-490. [CrossRef]

71. Venables, W.N.; Ripley, B.D.; William, N.V. Modern Applied Statistics with S-Plus; Springer: New York, NY, USA, 2002.

72. Borcard, D.; Legendre, P.; Drapeau, P. Partialling out the spatial component of ecological variation. Ecology 1992, 73, 1045-1055. [CrossRef]

73. Real, R.; Barbosa, A.M.; Porras, D.; Kin, M.S.; Márquez, A.L.; Guerrero, J.C.; Palomo, L.J.; Justo, E.R.; Vargas, J.M. Relative importance of environment, human activity and spatial situation in determining the distribution of terrestrial mammal diversity in Argentina. J. Biogeogr. 2003, 30, 939-947. [CrossRef]

74. Blüthgen, N.; Simons, N.K.; Jung, K.; Prati, D.; Renner, S.C.; Boch, S.; Fischer, M.; Hölzel, N.; Klaus, V.H.; Kleinebecker, T.; et al. Land use imperils plant and animal community stability through changes in asynchrony rather than diversity. Nat. Commun. 2016, 7, 1-7. [CrossRef] [PubMed]

75. Verburg, P.H.; Crossman, N.; Ellis, E.C.; Heinimann, A.; Hostert, P.; Mertz, O.; Nagendra, H.; Sikor, T.; Erb, K.H.; Golubiewski, N.; et al. Land system science and sustainable development of the earth system: A global land project perspective. Anthropocene 2015, 12, 29-41. [CrossRef]

76. Holzkämper, A.; Fossati, D.; Hiltbrunner, J.; Fuhrer, J. Spatial and temporal trends in agro-climatic limitations to production potentials for grain maize and winter wheat in Switzerland. Reg. Environ. Chang. 2014, 15, 109-122. [CrossRef]

77. Tuanmu, M.N.; Jetz, W. A global, remote sensing-based characterization of terrestrial habitat heterogeneity for biodiversity and ecosystem modelling. Glob. Ecol. Biogeogr. 2015, 24, 1329-1339. [CrossRef]

78. Skowronek, S.; Ewald, M.; Isermann, M.; Van De Kerchove, R.; Lenoir, J.; Aerts, R.; Warrie, J.; Hattab, T.; Honnay, O.; Schmidtlein, S.; et al. Mapping an invasive bryophyte species using hyperspectral remote sensing data. Biol. Invasions 2017, 19, 239-254. [CrossRef]

79. Lausch, A.; Bannehr, L.; Beckmann, M.; Boehm, C.; Feilhauer, H.; Hacker, J.M.; Heurich, M.; Jung, A.; Klenke, R.; Neumann, C.; et al. Linking Earth Observation and taxonomic, structural and functional biodiversity: Local to ecosystem perspectives. Indic. Ecol. 2016, 70, 317-339. [CrossRef]

80. Rocchini, D.; Luque, S.; Pettorelli, N.; Bastin, L.; Doktor, D.; Faedi, N.; Feilhauer, H.; Féret, J.B.; Foody, G.M.; Gavish, Y.; et al. Measuring $\beta$-diversity by remote sensing: A challenge for biodiversity monitoring. Methods Ecol. Evol. 2018, 9, 1787-1798. [CrossRef]

81. Siebert, S.; Portmann, F.T.; Döll, P. Global patterns of cropland use intensity. Remote Sens. 2010, 2, 1625-1643. [CrossRef]

82. He, K.S.; Bradley, B.A.; Cord, A.F.; Rocchini, D.; Tuanmu, M.N.; Schmidtlein, S.; Turner, W.; Wegmann, M.; Pettorelli, N. Will remote sensing shape the next generation of species distribution models? Remote Sens. Ecol. Conserv. 2015, 1, 4-18. [CrossRef]

83. Zimmermann, N.E.; Edwards, T.C.; Moisen, G.G.; Frescino, T.S.; Blackard, J.A. Remote sensing-based predictors improve distribution models of rare, early successional and broadleaf tree species in Utah. J. Appl. Ecol. 2007, 44, 1057-1067. [CrossRef] [PubMed]

84. Fahrig, L. Effects of habitat fragmentation on biodiversity. Annu. Rev. Ecol. Evol. Syst. 2003, 34, 487-515. [CrossRef]

(C) 2020 by the authors. Licensee MDPI, Basel, Switzerland. This article is an open access article distributed under the terms and conditions of the Creative Commons Attribution (CC BY) license (http://creativecommons.org/licenses/by/4.0/). 